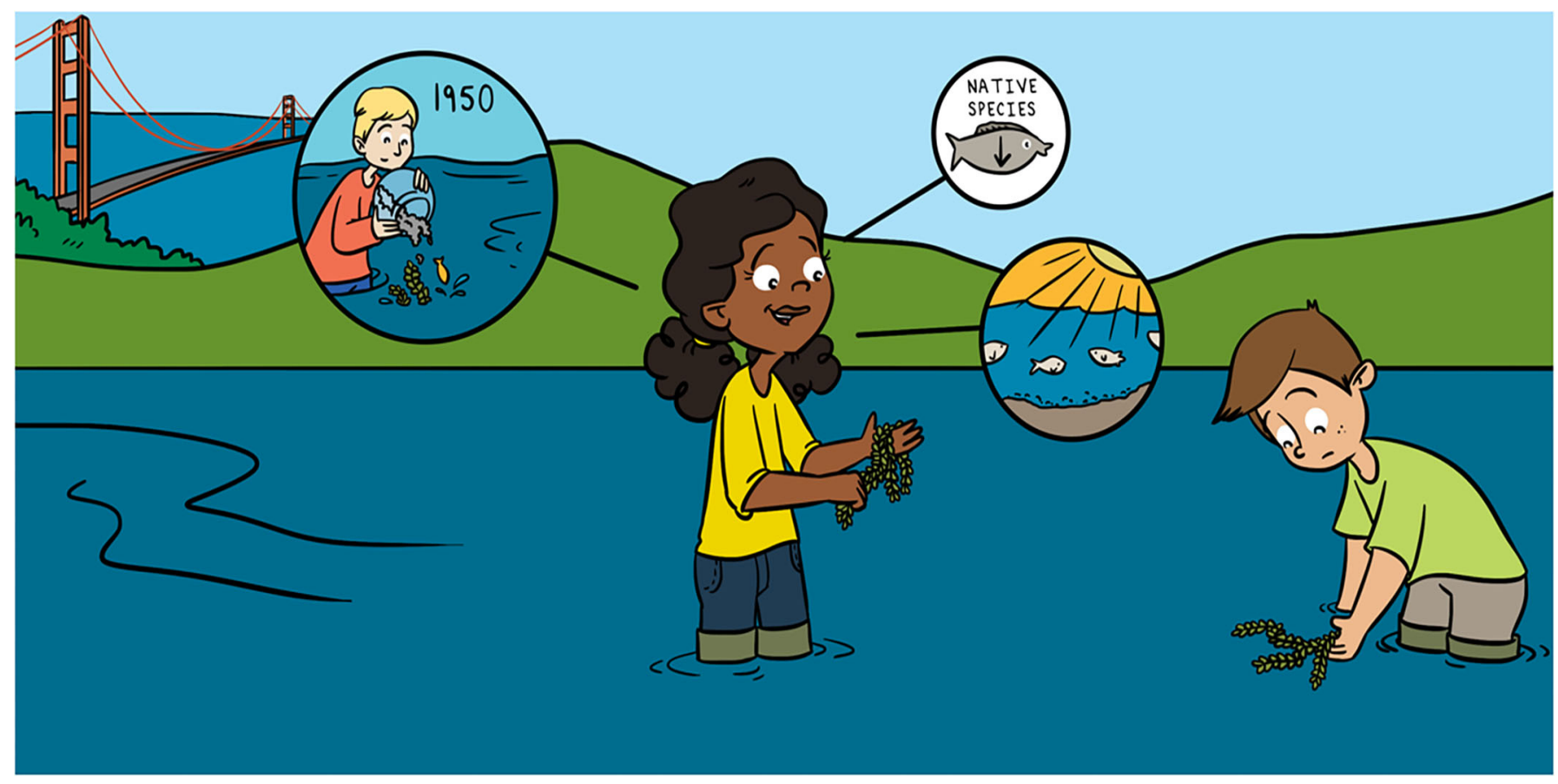

\title{
CAN PLANTS BE ENGINEERS?
}

\section{J. Louise Conrad *}

Delta Science Program, Delta Stewardship Council, Sacramento, CA, United States

YOUNG REVIEWERS:

EUROPEAN SCHOOL OF VARESE AGES: $10-11$
When we think of engineers, we think of making a machine, like a car. Are there engineers for ecosystems? When an organism can make big changes to its environment, we call it an ecosystem engineer. In aquatic ecosystems like the San Francisco Estuary, underwater plants can be important ecosystem engineers because they can change water flow and water clarity. In the Estuary, a plant called Brazilian waterweed, which was introduced by humans, is one of the most important ecosystem engineers. With its leaves and stems, this plant traps tiny particles floating in the water, making the water clearer. Clearer water has made it easier for more plants to grow and these changes helped some non-native fish species to increase in number, while some native species declined. Introduction of Brazilian waterweed has led to an entirely different ecosystem, which has also affected how people use and take care of the Estuary.

\section{WHAT ARE ECOSYSTEM ENGINEERS?}

What do you think an engineer does? Human engineers make things, like machines or buildings. So, what would it mean for an animal or 
ECOSYSTEM

\section{ENGINEER}

Any organism that

changes its

environment through

its actions (such as

beavers cutting down

trees) or its physical

structure (such as

underwater plants

trapping tiny particles

in the water).

WETLAND

Land that is saturated with water. Marshes and bogs are all types of wetlands.

INTRODUCED

\section{SPECIES}

Species brought to an ecosystem by humans, either on purpose or by accident. In aquatic ecosystems, humans can accidentally bring new species on the outside of their boats.

\section{NATIVE SPECIES}

Species that are living in a region where they originally evolved. Another term with the same meaning is "indigenous species."

\section{INVASIVE SPECIES}

Species that are introduced to a new to an ecosystem and cause harm to it, such as outcompeting and displacing the species that were already living there.

\section{SEDIMENT}

Solid material that settles to the bottom of a lake, river, or any waterway. Sediment can consist of particles of rock, minerals, and the remains of plants or animals.

PHYTOPLANKTON

Tiny, microscopic organisms living in the water that get their energy from the sun, just like plants. a plant to be an ecosystem engineer? Scientists that study animal and plant communities use this term to describe living organisms that make big changes in their own environments [1].

Beavers are a great example of ecosystem engineers. Beavers have sharp teeth that they use to cut down entire trees! They pile the cut wood on streams and rivers, making a dam. Once they finish, the water level above the dams rises, creating a pond. The edges of the pond also flood, creating a new habitat called a wetland. These new ponds and wetlands attract new species of fish, insects, and even birds. Is that not incredible? There are many other examples of ecosystem engineers, like termites and ants that build mounds and tunnels in the soil. While engineering these mounds and tunnels, they change how water drains through the soil and even the types of plants that can grow in that area [1].

\section{WHAT ARE INVASIVE ECOSYSTEM ENGINEERS?}

You now know that ecosystem engineers can be very powerful. Now, let us think about what happens when an ecosystem-engineering species comes to a place where it has never been before. In general, introduced species are brought by humans, either on purpose or by accident, to an ecosystem that is different from where they originally evolved. When the introduced species is also an ecosystem engineer, it can change how the ecosystem works, and even which other species will live there.

Many species are introduced to a new ecosystem, but never thrive in it. Some, however, can become quite at home and spread throughout the ecosystem, competing for food and space with the native species that already live there. When this happens, these introduced species are called invasive species.

When invasive species are also ecosystem engineers, they can change the basic parts of an ecosystem and cause harm to native species. Crayfish are a good example. Crayfish are ecosystem engineers because they burrow in the sediment to find food. When they invade rivers and lakes that have underwater plants, their digging destroys plant roots, and the plants die. When those plants die, other tiny plant species that float in the water, called phytoplankton, start thriving because the larger plants are no longer in the way. Through their extensive burrowing, crayfish can be invasive ecosystem engineers because they cause underwater plants to disappear and allow the phytoplankton to increase. Imagine how these changes might affect animals that were used to feeding on or living on the underwater plants. They might not be able to live in their home lake or river anymore. In general, once an invasive ecosystem engineer has made its home in a new place, it is likely that the ecosystem will never be the same again. 
Figure 1

Ecosystem engineering by aquatic plants. (A) The water initially has many suspended particles, making it murky and cloudy. (B) When the first aquatic plants begin to grow, they capture some of the suspended particles, and cause other particles to fall to the bottom as sediment, creating a small patch of clear water. (C) As the plants continue to clarify the water, more plants grow because sunlight can penetrate deeper into the water.

\section{ESTUARY}

The body of water where a river connects with the ocean and the waters are affected by the rise and fall the ocean tides.

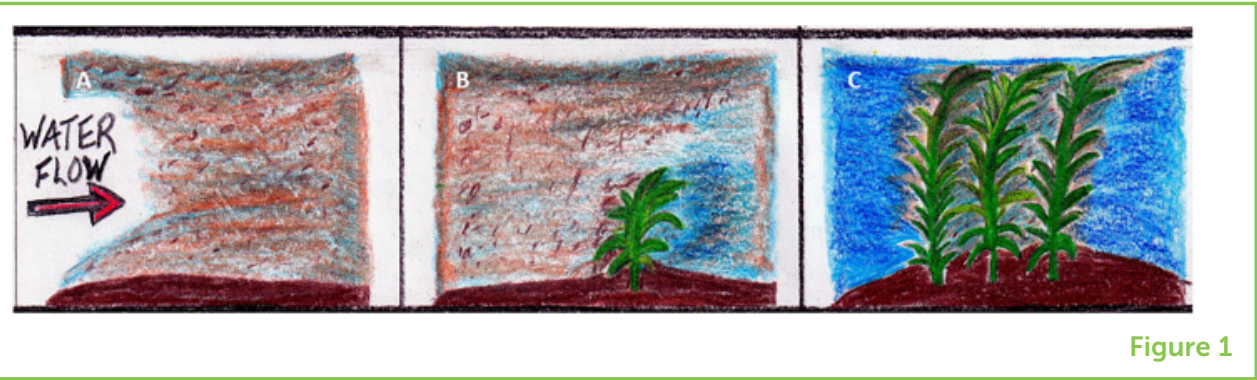

\section{PLANTS CAN ALSO BE ENGINEERS}

In rivers and estuaries, underwater plants (called aquatic plants) are some of the best-studied invasive ecosystem engineers. The leaves and stems of aquatic plants slow the movement of water and trap tiny floating particles of silt or clay. When these particles encounter a patch of aquatic plants, some will get stuck on the plants or fall to the bottom, becoming part of the sediment. This trapping of particles makes the water clearer. The clearer the water is, the more sunlight that can penetrate. More sunlight is good for the plants because they need it to grow.

When a new aquatic plant arrives in an ecosystem, it will trap just some of these floating particles. The water will clear up in a small area around the plant. Slowly, as the water clears, the plant will get more sunlight, grow more, and a small patch of the plant will begin to spread out to cover a larger area, even a whole river from one side to the other in some cases! The more plants there are, the more sediment will build up on the bottom, eventually reducing the water depth (Figure 1). Brazilian waterweed (Figure 2) is one invasive ecosystem engineer that creates sediment, clears up the water, and reduces water depth. Let us look at what happens when this plant comes to a new ecosystem.

\section{INVASIVE AQUATIC PLANT ECOSYSTEM ENGINEERS OF THE SAN FRANCISCO ESTUARY}

In the San Francisco Estuary, Brazilian waterweed was introduced before 1950, probably because people threw away the fish and plants from their aquariums right into the Estuary waters (which is illegal to do now). Today, Brazilian waterweed has spread throughout the Estuary, and even though other aquatic plant species have been introduced, it is still the most dominant one. Some areas that had few plants 30 years ago are now nearly entirely covered with invasive plants. The invasion of Brazilian waterweed and other aquatic plants into the San Francisco Estuary has made the water clearer than it used to be. Scientists estimate that, in some areas, more than two-thirds of the increased clarity may be due to the spread of invasive ecosystem engineering plants [2]! In beds of Brazilian waterweed, sediment can accumulate 
Figure 2

(A) Brazilian

waterweed, after being pulled out of the water with a rake. (B) A thick bed of Brazilian waterweed in the San Francisco Estuary. (Photo credit: J. Louise Conrad).

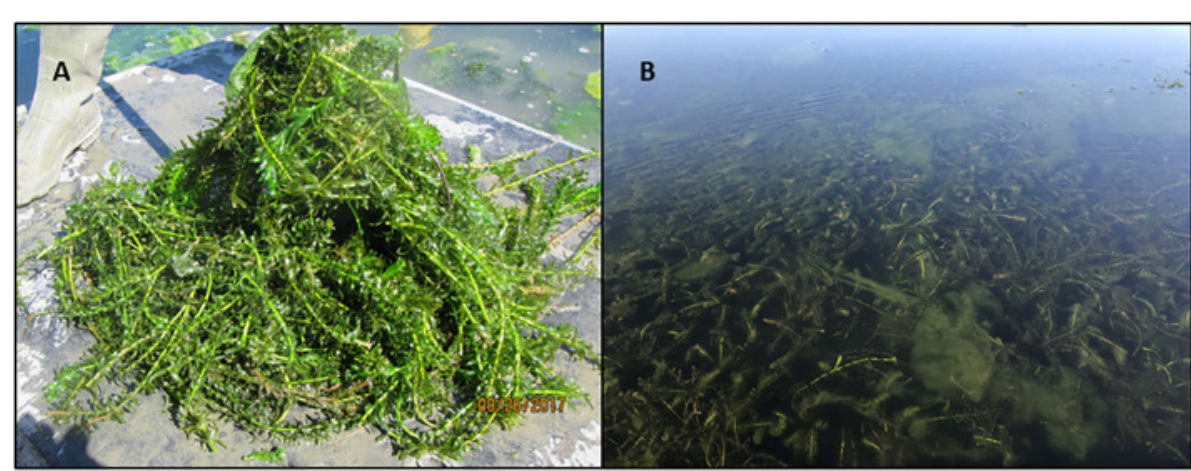

Figure 2

twice as fast as it did before in shallow areas of the San Francisco Estuary [3].

Brazilian waterweed in the San Francisco Estuary has also changed the fish species that live in shallow areas. Previously, shallow areas had native fishes such as perch and minnows. Baby salmon also used shallow areas to feed, as they traveled through the Estuary to get to the ocean. Today, it is much more common to see introduced fish species such as largemouth bass and sunfish (Figure 3). What is the connection between Brazilian waterweed and the change in the most common species of fish?

Largemouth bass and sunfish were introduced into the San Francisco Estuary over a 100 years ago, long before Brazilian waterweed. For many years, these fish were not very common. However, once the invasive plants became widespread, the numbers of largemouth bass and sunfish increased [4]. These fish do well in clear water with lots of plants around them, and this is exactly the habitat that Brazilian waterweed creates. The clear water helps these fish to see and capture their prey. The plants offer hiding places to help small fish avoid deadly encounters with larger fish. Native fishes were accustomed to using murky water to hide from predators, but with the clear water created by the plants, native fish have nowhere to hide. So, with more predators such as largemouth bass, their chances of being eaten are much higher than they used to be. Unfortunately, the number of native fish has declined dramatically in the San Francisco Estuary.

\section{PLANT ENGINEERS ALSO CHANGED THE ESTUARY FOR PEOPLE}

When the plant ecosystem engineers changed the type of fish living in the San Francisco Estuary, they also changed people's lives. For example, it has become popular to fish for largemouth bass in the Estuary. There are now competitions to catch the biggest largemouth bass, and the reward for the winners can be a lot of money! But 
Figure 3

(A) Historically, the shallow-water areas of the San Francisco Estuary were probably cloudy, with relatively few submerged and floating plants, and were inhabited by native fishes such as tule perch, Sacramento blackfish, and migrating baby salmon. (B) Today, these shallow-water areas are filled with submerged aquatic plants that have clarified the water substantially, and there are floating plants at the water's edges. It is common to find non-native sunfish such as largemouth bass, redear sunfish, and bluegill sunfish.

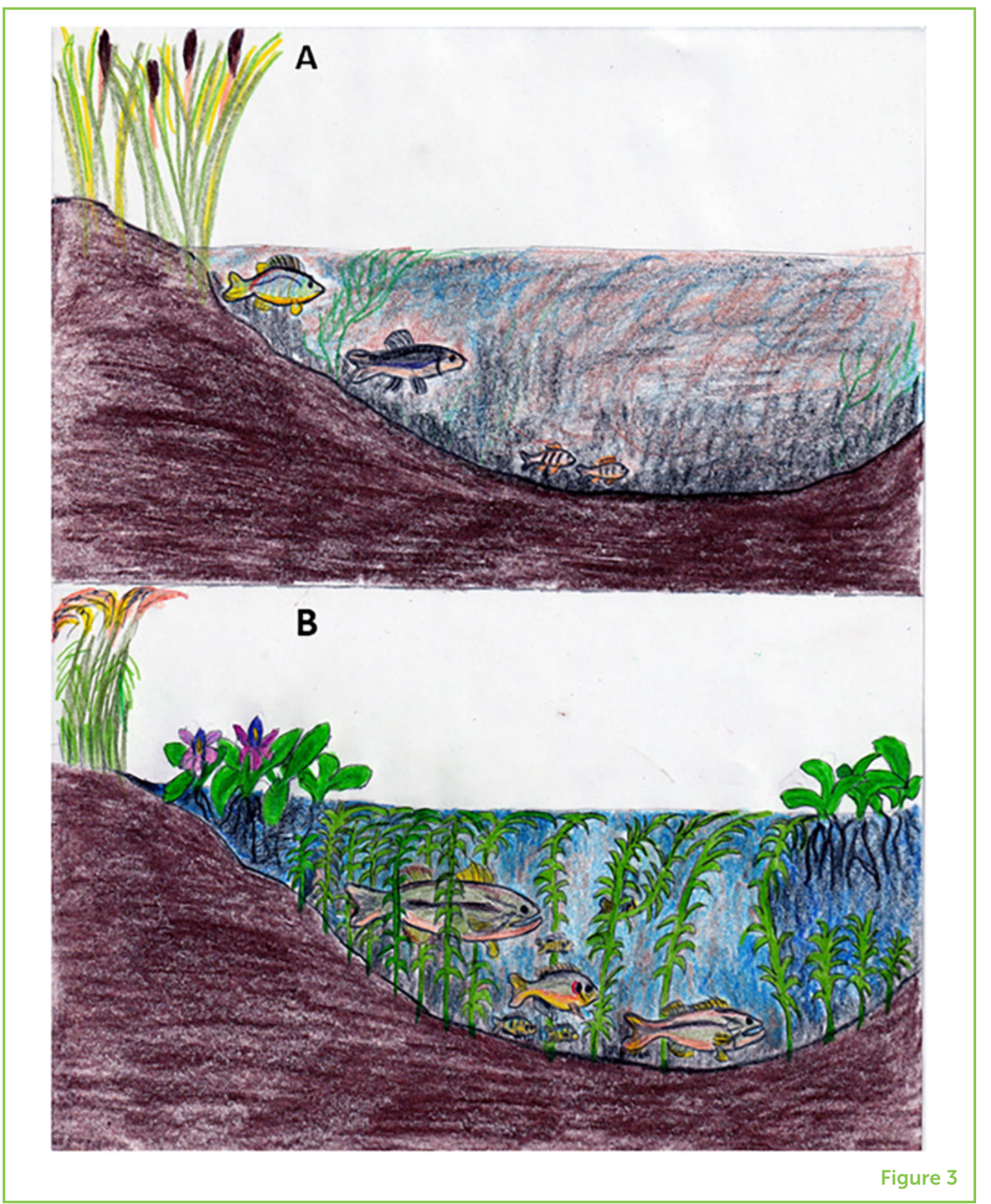

Brazilian waterweed is so thick in some areas it has made it hard for boats to move through the waterways. The California government has worked to control the plant using chemicals that keep it from growing. However, the plants have become so widespread that they are difficult to control, and they will probably always exist in the San Francisco Estuary. Scientists are working hard to understand which chemicals are safe and work best, and if there are other ways of controlling the plants.

There are many opinions about whether the changes brought by invasive ecosystem-engineering plants are "good" or "bad." It all depends on what we value in the ecosystem: whether we value having historical habitats like wetlands and native fish species, or whether we value fishing for largemouth bass. It is up to the people living in and 
using the San Francisco Estuary, as well as the governments in charge of managing it, as to whether the invasive populations of plants and fishes should be diminished. Despite these differences in opinion, we can all agree that, when invasive plants are ecosystem engineers, they can have widespread effects on the rest of the ecosystem, from fish to people!

\section{REFERENCES}

1. Jones, C. G., Lawton, J. H., and Shachak, M. "Organisms as ecosystem engineers," in Ecosystem management, eds F. B. Samson and F. L. Knopf (New York, NY: Springer). p. 130-47.

2. Hestir, E. L., Schoellhamer, D. H., Greenberg, J., Morgan-King, T., and Ustin, S. L. 2016. The effect of submerged aquatic vegetation expansion on a declining turbidity trend in the Sacramento-San Joaquin river delta. Estuar Coasts. 39:1100-12. doi: 10.1007/s12237-015-0055-z

3. Drexler, J. Z., Khanna, S., and Lacy, J. R. 2020. Carbon storage and sediment trapping by egeria densa planch., a globally invasive, freshwater macrophyte. Sci Total Environ. 755:142602. doi: 10.1016/j.scitotenv.2020.142602

4. Brown, L. R, and Michniuk, D. 2007. Littoral fish assemblages of the alien-dominated Sacramento-San Joaquin Delta, California, 1980-1983 and 2001-2003. Estuar Coasts. 30:186-200. doi: 10.1007/BF02782979

SUBMITTED: 02 November 2020; ACCEPTED: 10 September 2021; PUBLISHED ONLINE: 15 October 2021.

EDITED BY: Pedro Morais, University of Algarve, Portugal

CITATION: Conrad JL (2021) Can Plants Be Engineers? Front. Young Minds 9:625070. doi: 10.3389/frym.2021.625070

CONFLICT OF INTEREST: The authors declare that the research was conducted in the absence of any commercial or financial relationships that could be construed as a potential conflict of interest.

COPYRIGHT @ 2021 Conrad. This is an open-access article distributed under the terms of the Creative Commons Attribution License (CC BY). The use, distribution or reproduction in other forums is permitted, provided the original author(s) and the copyright owner(s) are credited and that the original publication in this journal is cited, in accordance with accepted academic practice. No use, distribution or reproduction is permitted which does not comply with these terms.

\section{YOUNG REVIEWERS}

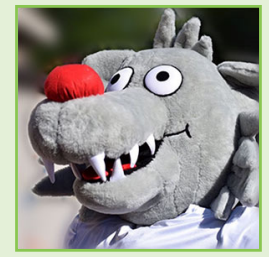

\section{EUROPEAN SCHOOL OF VARESE, AGES: $10-11$}

Hey! We are in 5th class in a European School. Most of us are 11 years old and speak English. We all come from different countries that have different traditions. However, we always try to work as a team, and so far, we have successfully achieved 
that. We are always trying to reach the best possible outcome and help each other. Our class has a wonderful teacher who has taught us a lot throughout the year. We are very happy and fortunate to take part in this project and hope for the best in the future.

\section{AUTHOR}

\section{J. LOUISE CONRAD}

When I was a child, my family spent many summers traveling across the United States. We enjoyed natural places along the way, and I loved to explore during our hikes. After that, I knew I wanted to study the environment and how people use it. When I was 20, I took a fish biology course from an inspiring professor, and I decided to keep studying fish. After completing my Ph.D., I led a study in the San Francisco Estuary about how fish interact with invasive plants, spending half my time on a boat! I am still fascinated with the shallow waters of the Estuary. *Louise.Conrad@adeltacouncil.ca.gov. 